\title{
Bordering through domicide: spatializing citizenship in Calais
}

\author{
Travis Van Isacker ${ }^{\mathrm{a}}$

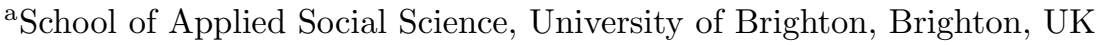

\section{ARTICLE HISTORY}

Compiled June 14, 2019

\begin{abstract}
This paper examines domicidal practices against illegalized border crossers in Calais, France as a technology of citizenship and migration governance. It addresses recent calls to include actions and interventions which restrict citizenship in the context of illegalized migration within critical citizenship studies literature. Studying the state violence upholding and spatializing normative citizenship allows for a deeper understanding of citizenship's implication in the European border regime, and raises questions on the concept's continued application to theorizations of migrants' political movements and spatial manifestations. The paper proposes anti-citizen politics as an alternative before arguing that the presence of this politics within the city's squats and jungles, more than the physical occupations as such, is what the French state seeks to eradicate through acts of domicide. Working from empirical examples, the article describes a 'carrot-and-stick' domicide currently at work in Calais where the eviction and destruction of autonomous forms of migrant inhabitance is combined with a simultaneous offer of state managed accommodation. These tactics operate together to drive migrants out of the city of Calais, away from the UK border, and ultimately into a determination of their detain/deport-ability via citizenship's scrutiny.
\end{abstract}

\section{KEYWORDS}

Calais, France; domicide; technologies of citizenship; anti-citizenship; spatial inhabitance/segregation

\section{Introduction: Acts of exclusion}

Illegalized migrants taking space in their daily movements resisting and subverting the European border regime has lead to intense debate on the implications for contemporary notions of citizenship. Recent special issues within this journal (see 20.5 Ataç, Rygiel, and Stierl (2016) and 21.6 Maestri and Hughes (2017)) have highlighted how these actions spatially constitute substantive citizenship and undermine citizenship's strict conception as a legal category determining political existence within a territory. Throughout these discussions runs a tension between 'migrant citizenship' scholarship and the 'autonomy of migration' perspective (Nyers 2015). The former reads migrant spatial ruptures and contentious inhabitance into the politics of citizenship to complicate the concept, while the latter instead reads them through 'the commons'. Although differing in their conclusions as to whether migrants' occupations and protests should be incorporated into the language and politics of citizenship, the 
two analytical veins share a methodological approach; interrogating citizenship from the perspective of illegalized migrants' struggles to move and stay as they please.

This article takes a slightly different tack. Rather than analyzing citizenship through migrants' spatial ruptures and forms of contentious inhabitance, it instead looks at how the state reacts to these ruptures, how those reactions reinforce normative citizenship, and how citizenship itself functions as a tool of migration control within the context of Calais, France. It responds to calls by Fortier (2016) and Darling (2017) to produce analyses of actions which delimit citizenship and further entrench it as a condition of the privileged few within critical citizenship studies. While the literature spawned by 'acts of citizenship' (Isin and Nielsen 2008) which Fortier and Darling address celebrates migrant activism as the motor of a progressive drive towards egalitarian citizenship (perhaps even an unbordered future), we must keep in mind citizenship's continued role as a primary tool for control of human mobility. Therefore, studies explicating 'techniques of governmentality deployed by states' which reestablish a normative and exclusionary definition of citizenship (Fortier 2016, 1040), as well as those 'spaces formed around exclusionary acts of citizenship' which 'are actively destructive of other ways of being' (Darling 2017, 734) are urgently needed. A critical understanding of the ways citizenship is used to govern migration not only shows how and by whom citizenship becomes restricted, but raises further questions on the techniques of capture present within citizenship itself while suggesting ways to subvert them.

The argument here then concerns itself with the citizenship of the police, in both real and Rancièrian terms, less than the (citizenship) politics of those struggling for the freedom of all to move and stay throughout Europe. Recognizing citizenship as historically an important imperial technology of subjugation and mobility control (Hindess 2004) as well as it's current inability to grasp the full political significance of contemporary migrations given its coloniality (Vázquez in Ansems de Vries et al. 2017, 8-9), this paper echoes calls for scholars to break with methodological citizenship in their analyzes of migration politics (Papadopoulos and Tsianos 2013; Tazzioli 2017a). However, citizenship nevertheless remains key to understanding state strategies and technologies of migration governance. Contrasting with the other papers in this special issue which show how migrants' squats, other contentious occupations, and their home-making practices illustrate political and spatial praxes which go beyond citizenship, I'd like to understand how and why these forms of inhabitance are evicted and destroyed. What is the state's strategy behind the domicide of migrant living spaces in Calais, how does domicide function as a political technology of citizenship, and how does state domicide contribute to establishing the citizenship regime as a fundamental technique of contemporary European migration governance?

Beginning by revisiting recent discussions on citizenship, space, and migration, a working conception of citizenship as a normative and exclusionary concept will be established before turning to how political contestations of citizenship manifest spatially. Building on the work of other geographers in the field (Mould 2017a,b), the second theoretical portion of the article establishes domicide as a political technology of citizenship fundamental to the state strategy of migration control in Calais. It functions by eliminating spaces in which people live their lives beyond and against citizenship's jurisdiction while channeling autonomous migrations into 'spaces of citizenship' where they can be captured and/or redirected into the state controlled circuits of mobility. Beginning with domicide's initial definition taken from Porteous and Smith (2001) as the deliberate destruction of home, criticisms and refinements will be made to the concept before applying it to the eviction and destruction of migrant living spaces in Calais. While there has been wide scholarly interest in migrant's spatial protests, the 
eviction, destruction, and erasure of those spaces remain understudied.

The second portion of the article illustrates how domicide functions in Calais by presenting empirical examples; the evictions creating the large jungle existing between Summer 2015 and Fall 2016, the multiple evictions and relocations of the inhabitants of a women and children's squat in 2014, and the current hyperactive campaign of domicide being waged against any form of shelter established by migrants in the city. These examples provide a broad impression of how domicide takes place in Calais across time, scale, and with different tactics, while showing how in each case the common goal remained the segregation of Calais' urban space as one of European citizenship, the spatial exclusion or containment of 'non-citizens', the gradual filtering of those 'non-citizens' into state controlled spaces of citizenship, and the elimination of autonomous spaces which undermined the citizenship regime.

\section{Spatializing citizenship and anti-citizen politics in Calais}

While citizenship can perhaps best be defined as a site of contest constituted by the struggle over it (Balibar 2009), this research focuses on one half of that struggle; the reterritorialization of the autonomous spaces 'non-citizens' inhabit by the state in its defense of citizenship. Here I deliberately mobilize a specific exclusionary and normative conception of the term. It is a recognizably limited understanding of citizenship; however, as the focus here is not on its content (the rights and responsibilities citizenship entails), nor how it can be expanded to encompass other-than-citizen political actions, this conception is nonetheless appropriate. The argument takes the state's own restrictive, though still hegemonic, definition to explore the production of 'non-citizen' spatial exclusion rather than work to redefine citizenship or discovering qualities attributed to it at work in the political mobilizations of the excluded.

Furthermore, the spatial perspective taken here refrains from speculating on others' political subjectivities, and focuses on the space and materiality of how citizenship is constituted, maintained, and mobilized in migration control strategies. Imagining citizenship as a tangible web distributed over space and imposing upon it a normative geometry of interactive possibilities denaturalizes spaces of abjection, and denormalizes the distinctions between classes of inhabitants. The writing of citizenship's logic into space orients people to or away from each other based upon the distance and arrangement of objects which make it up, and acts to restrict the possibilities and types of encounters within and across (non/citizen) groups (Isin 2002, 48-49). How bodies are arranged within space, the distances placed between them, and what spaces certain bodies are allowed to inhabit or are removed from according to the logic and distinctions inscribed by citizenship are political contestations imbued with histories of systematic domination and exclusion that become written into environments and then materially reinforced by them. While this article is principally focused on elaborating exactly how domicide is used to spatialize and materially enforce normative citizenship in Calais, it is first relevant to briefly explore the politics of migrant spatial inhabitance in rupturing citizenship, and how they pose an existential threat to it as governmental logic.

There have been a number of recent studies highlighting the importance of space in ordering and rupturing citizenship through examples of migrant struggles. Most recently, Contested spaces of citizenship argued citizenship is spatial because technologies and strategies of exclusion against 'non-citizens' are spatially manifested, and because taking space is a fundamental act by which migrants contest exclusion and 
demand (citizenship) rights (Maestri and Hughes 2017, 628). Space is shown to be an important factor within migrant struggles at many levels; from the choice of protest location to how that protest interacts with the space in which it takes place (Atac, Rygiel, and Stierl 2016, 538). This is not to mention most migrant protest actions are organized around the subversion and disruption of a decidedly spatial strategy of governmental control of movement, or their outright spatial exclusion through deportation or detention (Ataç, Rygiel, and Stierl 2016). However, beyond the appropriation of space within protest, the contentious inhabitance of space (be it through squatting buildings, occupying infrastructure or symbolic locations, or establishing and defending autonomous encampments) carries additional implications.

The contentious inhabitance of space amplifies the visibility of occupant's grievances, asserts the occupants as political subjects, and creates space and time for solidarities to develop across citizenship categories (see the other articles in the issue as well as Ataç (2016) and Mudu and Chattopadhyay (2017)). In Calais, squatted spaces established and shared by coalitions of illegalized migrants crossing to the UK, asylum seekers in France, European passport holders, and local Calaisiens went beyond providing material support to migrants in precarious living situations and created links of solidarity and mutual aid 'as people struggled together against police brutality and repressive border control mechanisms' (Calais Migrant Solidarity 2017, 62-63). Calais Migrant Solidarity describe how hunger strikes were organized and supported, evictions resisted, future squatting actions organized, locals politicized and radicalized, and information spread on navigating the British asylum system all from the personal relationships developed within just one of these squats. Natasha King $(2016,125)$ describes how these spaces 'built bridges between people with and without papers... [and] amounted to an experiment in equality that was also another way of being outside the state'. These experiments in 'being outside the state' as well as many of the concrete activities that took place in the squats of Calais represent what in this paper will tentatively be termed a politics of anti-citizenship.

This concept can be thought alongside (but goes beyond) the 'no border' politics sketched by Anderson et al. (2009; 2012) and King (2016) among others. It is the practical and everyday refusal to reinforce citizenship as a mechanism of bordering and exclusion by redefining relationships of cooperation and solidarity without reference to citizenship categories. It is a politics of coalition comprising people positioned across various categories of (non)citizenship status who together develop collective actions aimed at eliminating citizenship's arbitrary juridical distinctions and the privileges stemming them. It is performed both when those excluded from citizenship act in defiance of their exclusions and when those holding citizenship privileges mobilize them against the border regime and its underlying citizenship logic. Not a superficial opposition to citizenship, anti-citizen politics begins with deeply engaging the lived realities of inequality produced by citizenship's exclusions and differential inclusions whilst working towards their dismantlement. It is not prescriptive or didactic but is sensitive to migrants' strategic appropriations of citizenship to win material gains while remaining concerned with prefiguring spaces, structures, and mobilities outside and against citizenship.

The crucial difference between anti-citizenship politics and 'acts of citizenship' (Isin and Nielsen 2008) or 'citizenship from below' (Nyers and Rygiel 2012, 9) is, whilst similarly breaking from citizenship's primacy in determining who or what actions are allowed to count as political, anti-citizen politics actively seeks to undo citizenship. It focuses on collectively subverting and challenging its technologies (e.g. borders, detention, deportation, enforced destitution) while refusing to reproduce its categories in 
the movement's organizing and aims. Theoretically, a politics of anti-citizenship recognizes not only that it is impossible to separate citizenship from its juridical status and function of mobility control (De Genova 2017, 20), but also that every argument to expand citizenship rights is premised upon the deferred exclusion of another. As Amy Brandzel writes, ' $[\mathrm{t}$ ] here is no such thing as a movement of citizenship and inclusion for some that does not further the vulnerability and disenfranchisement of others' $(2016, \mathrm{x})$. Even when fighting for the widest possible inclusion, the logic of citizenship requires breaking apart wider solidarities across demographic or citizenship status categories: for example between 'Europeans' and 'migrants'; 'refugees', 'asylum seekers' and 'economic migrants'; or amongst countries of origin. There is a fundamental discord in establishing a politics of freedom to move and stay for all in citizenship rights, and perhaps instead we must begin this task by squarely opposing citizenship as subjectivity, political practice, and ultimate horizon.

I do not contend that anti-citizen politics is present in all actions targeting the border regime in Calais - indeed Rigby and Schlembach have shown how even during the 2009 No Border camp citizenship remained 'a way of defining and policing the borders of who and what could count as political' $(2013,158)$. Nor do I argue all forms of autonomous migrant inhabitance in the city necessarily manifest such politics - there exists an extremely complex and often ambiguous relationship between the spaces migrants end up calling home, segregation, exclusion, political resistance, and citizenship in Calais. ${ }^{1}$ Instead, I want to focus on the ways in which Calais' squats and jungles spatialize anti-citizenship politics, and then, more specifically, how and why they are targeted for elimination through state domicide. Indeed, although Mezzadra and Neilson would no doubt argue against an anti-citizen politics as it has been offered here - preferring instead to interrogate the 'frame and discourse of citizenship' than abandon it $(2013,261)$ - in their critique of No Borders they do laud the political spaces which have been opened up by its movements, and which are the subject here (268). These spaces enable anti-citizen politics across and against citizenship's distinctions by incubating their occupants from intrusion by the citizenship regime as represented by the police or access controls based on biometric registration or an asylum claim, and often exist to directly facilitate unauthorized border crossings. To the extent they refuse to reproduce, while providing a toe-hold from which to collectively resist, citizenship's fundamental distinctions and mechanisms of mobility control, these spaces could be said to possess an anti-citizen quality which becomes the ultimate target for elimination by the state.

\section{Refining domicide}

Geographers Porteous and Smith (2001, 19) initially theorized domicide as the 'planned deliberate destruction of home causing suffering to the dweller'. Thinking

\footnotetext{
${ }^{1}$ The city's squats and jungles can in one and the same time be places of segregation and exclusion, but also politicized spaces of struggle and resistance. They operate as a technology of citizenship as they 'deny and interrupt "presence" to people by hindering the visibility, association, recognition, status, and rights that come with being of the city' (Rygiel 2011, 14), while they also render hyper-visible people deemed to inhabit the camps when they are out in the city; produced as 'out of place' they are easily spotted, rounded up, detained, and sent back. However, these occupations are also collaboratively built and autonomously organized nodes in Papadopoulos and Tsianos' 'mobile commons' (King 2016, 107). This dual quality produces certain paradoxes in political organizing around such spaces. For example, 'The Jungle' existing between 2015-2016 was vehemently fought against when it was first proposed by the state as a 'tolerated' (and segregated) form of inhabitance, but then struggled for when faced with eviction (Ansems de Vries et al. 2017, 14-15).
} 
the elimination of anti-citizen spaces of inhabitance through domicide highlights the erasure as an act of violence committed by intentional actors who stand to profit, implement their ideological positions, or consolidate political power while representing these consequences as being for 'the common good' (184). Framing the evictions and destructions in Calais through domicide counters the paternalistic humanitarian narratives through which they are often justified by authorities. However, this initial definition must be refined to include the more nuanced ways domicide functions as a spatial technology of citizenship and migration governance in Calais.

For Porteous and Smith the material loss of home and the victim's resultant experience of suffering is the measure by which eviction is considered domicide $(2001,192)$. This criteria makes it difficult to recognize more nuanced tactics as domicide; perhaps where coercion or incentive is used so people 'willingly' leave their homes. There must be an expansion of the concept to encompass evictions which do not become spectacles as violent erasures nevertheless. Particularly in Calais where a 'carrot-and-stick' strategy is used, it is imperative to recognize actions which eventually result in the elimination of forms of anti-citizen inhabitance as domicide. In doing so, responsibility is attributed to the state actors who reassert citizenship status as determining one's right to inhabit the city through enacting domicide, and spatial exclusion, against 'non-citizens'.

Furthermore, the threshold of suffering in Porteous and Smith's original definition must also be reappraised. In their articulation domicide requires a persistent subjective experience of pain and mourning. However, groups of evictees are not homogeneous and amongst them there can be multiple attitudes towards the loss of a home, with some perhaps welcoming it. For example, some residents saw the eviction of 'The Jungles' in October 2016 as an opportunity to move to a more hospitable city or improve the material conditions of their lives in France. However, the implications of the removals greatly benefited the politicians' goal of eliminating migrant forms of inhabitance in Calais rather than provide a good faith solution to 'non-citizen's' accommodation needs, and even before the final evictions, many of those who left 'The Jungle' in 2016 chose to return after seeing that the alternatives they were sent to were not fit for their needs (Calais Writers 2017, 248).

The measure of suffering in Porteous and Smiths' original definition further victimizes targets of domicide, and limits the understandings and consequences of their resistant solidarities (Nowicki 2014, 791). Implying those removed from their homes can only, even requiring they must, suffer minimizes or altogether discounts direct acts of resistance and the personal empowerment generated by them. For example, again during 'The Jungle's' 2016 eviction, some residents decided to set their own homes on fire in protest rather than see them dismantled by state contracted workers (Calais Migrant Solidarity 2016). This example severely disturbs the position Porteous and Smith's definition gives to targets of domicide, as well as the victimizing narratives in which they are framed. Despite the superficial paradox of inhabitants spectacularly destroying their own dwellings in protest of the planned demolitions, these actions can be understood as mobilizing the limited means jungle residents had to resist given the overwhelming number of police present, and as a powerful refusal to reproduce the eviction's non-violent veneer. By setting fire to their homes the residents showed that the eviction was violent despite massive state efforts to prevent it being mediatized as such. In a bizarre and insulting attempt to maintain this facade even after the fires had begun, the Prefet of Nord/Pas-de-Calais, Fabienne Buccio, described the burning as a tradition the migrants had of setting their homes alight before departing (Reuters 2016). 
Apart from the eviction and material destruction of existing homes, domicide must also be recognized as the denial of homebuilding capacities. In Calais this has taken the form of police preventing volunteers from bringing in more durable materials like stone or brick which could be used to create permanent dwellings in 'The Jungle' (Mould 2017b, 7); police harassing and interrogating members of an aid association while they were distributing tents following an eviction in 2018 (Délinquants Solidaires 2018); and a continuous attempt from the city's mayor, Natasha Bouchart, to criminalize squatting in France (Le Figaro 2015). These are just three examples of attempts to remove the capacity of people to create autonomous forms of inhabitance, while also preempting the need for large scale and recognizably violent evictions and destructions. With domicide in Calais being made increasingly routine and invisible, it is imperative to continue recognizing and resisting all actions which are part of a domicidal strategy to prevent illegalized migrants from constructing shelters that contribute to the homeliness of space and the security of their inhabitance (Mould 2017a, 13).

Given the above criticisms, I will employ a strictly spatial definition of domicide as the intentional elimination of contentious spaces and forms of inhabitance. This is primarily by their material destruction, but also occurs through more opaque techniques (like coerced abandonment or actions which prevent development). Limiting the measure to whether or not an action contributes to the spatial erasure of inhabitance gestures towards the affective implications of erasure, but does not prescribe how those whose homes are being destroyed should experience the event or respond to it.

Domicide functions as a technology of citizenship both by physically destroying 'undesired' dwellings and by socio-symbolically prescribing normative forms of spatial inhabitance and citizenship (Nowicki 2017, 172). Within Calais, the destruction of 'non-citizen's' homes in the city segregates illegalized people beyond its territory and forces them to live in near invisibility, with often no more than the semblance of a shelter, and where they are heavily targeted by policing operations in an effort to exhaust and expel them further. Additionally, domicide is aims at breaking apart anticitizen communities and friendships of solidarity in resistance to the border/citizenship regime (Mould 2017b, 7). Although a fundamentally important technology through which normative citizenship is maintained and human mobility controlled, domicide has increasingly become just one half of the state's strategy in Calais next to the enclosure of the evictees within spaces of citizenship.

\section{Domicide as technology of citizenship in Calais, France}

\subsection{Calais' border}

Before detailing recent examples of domicide in Calais it is useful to briefly recount the history of its border and the consistent denial of migrant accommodation. Situated approximately fifty kilometers from the South-East Coast of Britain, Calais is the closest port to the United Kingdom. The Calais - Dover ferry crossings are the shortest and cheapest not to mention the Eurotunnel terminal which transports passengers and freight under the seabed in less than an hour. The ease with which commodities and those holding proper documents pass through the city's ports and onto the ships and trains bound for the UK contrasts sharply with the militarized infrastructure in place to prevent unauthorized persons from making the crossing. Most who cross the channel clandestinely from Calais do so by attaching themselves to these logistical 
flows, trying to not be recognized as an out-of-place human body amidst the tons of cargo and innumerable vehicles permitted to traverse the narrow waterway each day.

Calais, although on the European mainland, essentially became the territorial boundary of the UK with the signing of the Le Touquet treaty in 2003. This agreement established juxtaposed immigration controls on cross-channels ferry routes following an existing arrangement on crossings made through the Eurotunnel. This externalization of the UK border has made Calais into a choke point for migratory flows to the UK, with illegalized migrants being forced to spend months living precariously in the city whilst making their own attempts to cross clandestinely. Between 1999 and 2002 there was an accommodation center managed by the Red Cross for illegalized border crossers in Sangatte (a small town next to Calais). There they could stay and rest in between attempts, have basic needs met, and not be pursued by police or threatened with arrest while doing so. However, this center was closed down after a sustained media campaign in the British press which portrayed it as having a 'magnet effect' and being a 'pull factor' encouraging and facilitating irregular crossings into Britain (Buchanan and Grillo 2004). The campaign has continued to effect the rhetoric surrounding migrant accommodation in Calais with politicians still defending proposals against accusations of creating 'a new Sangatte' (Vincent 2014).

The closure of the Red Cross center in Sangatte did not stop people from traveling to Calais to try and cross to the UK, but rather pushed them into less visible and more precarious spaces of inhabitance during the time they spend there. With nowhere else to stay, migrants began living in autonomous squats and jungles in much larger numbers. These settlements would continue to grow, and again became large enough to attract the attention of the UK media in the late 2000s. In 2009 there was a rush of security infrastructure spending for the port of Calais from the UK, while on the French side the Minister of Interior and recently elected anti-migrant Mayor Natasha Bouchart evicted and bulldozed around 800 people from the Pashtun Jungle despite their resistance (Calais Research 2017). Again, this eviction did not prevent people from returning to Calais to make their attempts to cross. In the following years the numbers of illegalized border crossers would grow again, and the squats and camps would continue to proliferate.

Between 2009 and 2015 many squats and jungles existed in and around the city. These were often spaces established and primarily occupied by people seeking to cross to the UK (although there were also inhabited by people in various stages of regularizing their status in France as well as European passport holders). They were heavily targeted by French police, with raids, identity controls, arrests, and eviction, destruction, and re-occupation a constant cycle of life in them. Following the large number of arrivals in Summer 2014, a series of evictions and destructions around the city resulted in the consolidation of most of the migrant population in a single large encampment for the first time since Sangatte. Whilst this occupation was but one of the many jungles that have existed in the city, its size and visibility meant it was again exceptionally mediatized in the UK and eventually evicted and destroyed. Yet, continuing the repetitive cycle, after 'The Jungle' was obliterated and its inhabitants dispersed in October 2016, people continue returning to Calais to attempt their clandestine crossings, and now faced the most hyper-active and sustained campaign of domicide the city has ever seen. 


\subsection{The 'carrot and stick' of domicide and state accommodation}

Calais is a site where territorial exclusion from the UK and intense internal migration policing in France converge. People presumed to be threatening the UK's border (often based on their living in autonomous spaces) are targeted in acts of domicide as a way to direct them into state managed 'accommodation'; either the detention centers or to the 'reception and orientation centers' - Centres d'accueil et d'orientation (CAO). The latter is for those who choose to claim asylum in France whilst the former for those who refuse. These places require people to be filtered and processed upon entrance by state bureaucracy in accordance with the citizenship regime in order to determine their deportability or detainability (De Genova 2007).

The provision of accommodation by the state depending upon or directing into an asylum claim (and often an eventual rejection) is merely the other side of the domicidal policies against autonomous migrant living spaces in Calais. While in previous years there were no accommodation solutions for evicted migrants (the local government always hoped they would just leave the city once their homes were destroyed), now the violent destructions are taken as an opportunity to bring evictees within 'spaces of citizenship'. Martina Tazzioli (2017b) describes this shift in tactic as 'expulsions of humanitarianism'; quoting one NGO worker as saying 'it is an eviction that is conducted for the benefit of the migrants, that is for transferring them into the circuits of the hosting system'. Despite this humanitarian veneer it is important to still recognize such evictions as domicide implicated within the wider border and citizenship regimes, and a fundamental node in the system of mobility control.

Carrot-and-stick domicide eviction and destruction alongside inclusion within 'spaces of citizenship' - is the primary way in which citizenship is today spatialized in Calais. Those spaces which provide refuge outside of the citizenship regime, foster solidarities against and despite citizenship, and which carve out spaces for people to live autonomously beyond the detention centers or asylum seeker accommodation are targeted for elimination.

The policy of governing the city's migrant population through this 'carrot-and-stick' is acknowledged at the highest levels. French President Macron put it bluntly when stating migrants should understand " $[\mathrm{t}$ ] o stay in Calais and build makeshift shelters or squats is a dead end. The alternative is clear; people can get to the reception centres where everyone's case will be examined and those who have the right, given asylum in our country' (Willsher 2018). These statements have provided the political and ideological justification for France's current extreme campaign of domicide in Calais following the eviction of the Jungle in October 2016. A report by the French Ministry of Interior shows that between May and August 2017 eighty 'anti-squat' operations took place, resulting in 195 destroyed occupations, and a total of 91,000 kilograms of destroyed belongings including shelter material, clothes, and other personal effects (Diaz et al. 2017, 32) while human rights observers counted 393 separate eviction operations between November 2017 and November 2018 (L'Auberge des Migrants et al. 2018). Currently, police visit and destroy migrant occupations multiple times per week, collecting and throwing away any objects which are left in the area after people have fled (Refugee Info Bus 2018a,b,c). These actions reflect the obsession within both local and national government to achieve 'zero squats in Calais' after the eviction of 'The Jungle' in 2016 alongside a paranoia towards the development of points de fixationessentially any location where migrants are visible in the city or where they are able to access services.

This campaign of domicide is part of what has been called a wider "politics of 
exhaustion' (Ansems de Vries and Welander 2016) operating against migrants in Calais and other European borderzones. Through a combination of uncertainty, enforced mobility (e.g. eviction, harassment, and deportation) and immobility (e.g. detention and waiting) it aims to break human bodies and spirits so that migrants opt themselves for abandoning further unregulated movement; that they recognize the 'dead end'. In Calais, the constant destruction of the material infrastructure needed for survival as well as the daily evictions keeping migrants on the move within police dictated circuits of mobility points to Macron's 'alternative' of moving to a state managed center as the only way out. With autonomous modes of inhabitance constantly being violently erased, the desires of the French state are clear; enter into the spatial circuits of citizenship, submit to the scrutiny of the asylum and regularization process here, and forgo an onward journey to the UK.

As briefly mentioned, this current provision of state accommodation alongside the enactment of domicide is a relatively new development in the state's migration control strategy. In the following examples it will be shown how domicide has been used previously to spatially segregate the migrant population and exclude them from the city. Looking at the creation of 'The Jungle' through two concurrent domicidal processes (one of a squat providing migrant family accommodation and the other of all other squats and jungles in the city), the following cases show how domicide operated to reinforce normative forms of spatial inhabitance based upon citizenship status, and was mobilized against spaces nurturing anti-citizenship solidarities.

\subsection{The long domicide of the women and children's house}

The women and children's shelter began as a squat within Calais' city center and was originally squatted by people with citizenship privileges in 2014. It was maintained as an autonomous space for most of its existence, in conflict with local government and the courts, and with no budget except for donations collected to pay for water, electricity, and gas. The squat was managed collectively by the women and their families, European residents with citizenship privileges, local neighbors, and other visitors from Calais. The residents lost their legal right to occupy the building with a court decision on November 19th, 2013 (Calais Migrant Solidarity 2013a) although the Prefect stated the police would not immediately act to evict the building (Calais Migrant Solidarity 2013b).

This decision to not evict was perhaps because the migrants housed were predominantly women and children, and the squat was receiving a lot of local support. Instead the Prefecture engaged the squatters in a negotiation regarding the occupation. While the ensuing discussions represented a significant shift in the way the state approached a squat in Calais, the threat of a violent eviction still loomed over the residents (King $2016,114)$. The state's conditions were that only migrant women and children were allowed inside, and its current European residents would have to leave the squat to allow a contracted NGO to take it over. If these conditions were refused, the prefect said that the responsibility for the ensuing eviction would be on those Europeans who squatted the building and began the project for refusing to leave. Whilst not an uncontested decision, the non-migrant residents eventually left the squat and the NGO workers moved in.

Overnight this changed the lives of all the squat's residents and took away the social and communal (if not physical) space which had been shared and struggled for together over the last year. Furthermore, it brought an autonomous space under state control 
and ensured, through the introduction of state contracted NGO workers, the future evictions of the remaining residents would be easier. With this first eviction the state's target was less the occupation or the migrant residents themselves, but rather the anti-citizen politics found inside the squatted house which came from the solidarities amongst European and migrant squatters. At the time it was a space existing within the urban city center of Calais, but which explicitly refused to reproduce the spacial segregation of 'non-citizen' people in the city. The residents sought to establish equality amongst themselves based on a sensitivity to how life in Calais remained very different for each of them (King 2016, 110-115). A main purpose of the squat was to enable crossing attempts, and so the women were free to come and go through the night, and stay as they pleased without external conditions being placed on them or restricting their access. When taking over the running of the squat the state made the concession of not fingerprinting the residents and still letting them come and go throughout the night, but still saw an opportunity to filter the residents into the citizenship regime in ways which hadn't existed before by charging NGO workers to register and establish the situation of each of each person living inside and then report on it (La Voix du Nord 2014b). Furthermore, the state proposed women and children should only be able to stay for two months before being directed to 'more appropriate solutions' (La Voix du Nord 2014a).

After taking physical control of the site and introducing a contracted NGO to manage it, the government still had to remove the remaining inhabitants and end the contentious occupation. It was a big contradiction for the state to contract an NGO to work inside of a space which had been autonomously reclaimed, and whose occupation was deemed illegal by the court. Thus came the task of finding another location to house the remaining residents. The first building proposed was located in Calais-Nord, the historic city center. Natasha Bouchart intervened in order to prevent this; specifically citing the close proximity of this location to both the food and clothing distribution areas, and because it was in the middle of Calais-Nord 'where there are already many problems with the migrants' (La Voix du Nord 2014a). Instead, she unilaterally requisitioned a space belonging to another NGO five kilometers away from the center to house them (La Voix du Nord 2014a). The women and children did not want to move there, but were forced to against their will. They were to be excluded from the city center, and the social networks and services it contained. The residents would again be forced to move into the Jules Ferry Centre in late March 2015 when the state began creating 'The Jungle' after nearly another year in this second location. Again, this was not what they wanted for themselves, but they were forced to under threat of police violence (Calais Migrant Solidarity 2015a). The NGO workers managing the project also encouraged them to go at each point, ensuring the domicides would proceed smoothly and be unnoticed.

The repeated and invisible acts of domicide against the women constituted the enclosure of anti-citizen spatial ruptures, and was the beginning of the segregation of most of almost all of Calais' illegalized border crossers as will be shown in the next section. At each moment the threat of police violence was used, if not directly enacted. However, these evictions did not take place without violence but were violent in and of themselves. They broke apart anti-citizen solidarities and interpersonal relationships, they uprooted families and thrust them into unknown locations further and further from the city center, and allowed the state regime of citizenship to enter into their lives by imposing conditions and time-limits upon access to a sleeping space. 


\subsection{Creating 'The Jungle'}

It was around the Jules Ferry Centre now housing the women and families that 'The Jungle' was to be constructed. While April 5th, 2015 is the day the riot police forcibly removed people in the first camps targeted - making them leave behind their possessions and destroying their homes and belongings to create 'an instant archeology of the migration crisis' (Davies and Isakjee 2015, 93) - this violence only punctuated a much longer process of domicide. The slow domicide resulting in 'The Jungle' included the displacement of food distribution, water points, and showers for migrants from the city itself to the abandoned children's camp Jules Ferry several kilometers outside. It also consisted of re-settling many of those who had already claimed asylum in Calais to other cities across France, the previously discussed rehousing of the women and families, and the daily harassment by police and workers of the French immigration office of those staying in the other autonomous camps and squats throughout the city (Calais Migrant Solidarity 2015b). These events did not occur without resistance, and many people chose to stay put despite the constant early morning threats by police to move further out of town or face arrest.

While the autonomous jungles were evicted and their inhabitants told to move down the road (the Centre Jules Ferry was located on the far side of what was an overground shrub-land at the end of Rue des Garennes along which hundreds of people were already staying), the occupations in the city center continued. Many people refused to leave their homes and live in the state's newly created 'tolerated zone'; citing distance from the city, environmental conditions, and the fear of police control (Calais Migrant Solidarity 2015f). On June 2nd both the jungle out by the Eurotunnel terminal and a large squatted metal recycling facility-home to around four-hundred people and occupied for almost one year (Calais Migrant Solidarity 2017, 63) — were evicted by large numbers of police (Calais Migrant Solidarity 2015c). On September 22nd, the final evictions and destructions took place of the predominately Syrian groups remaining in the city and occupying a few locations. Those evicted in these actions were told by police to go to the jungle. They refused, sat down in the middle of the road and began chanting 'No Jungle! No Jungle!' (Calais Migrant Solidarity 2015d). The line of riot police reacted by tear-gassing the group and then frog-marching them for almost four kilometers all the way to the jungle (Solla and Menendez 2015). As they approached, those people camping along Rue des Garennes West of the A16 motorway bridge were also removed from their homes and had their tents destroyed by the same police line and pushed into the dune-land past the highway access ramp. This marked the elimination of all visible autonomous migrant occupations in the city and their consolidation into one territory where they were left to self-organize their living together in an increasingly shrinking space (Davies, Isakjee, and Dhesi 2017).

Seeing how the establishment of a migrant day center in Jules Ferry as well as the French state's tolerance of an autonomous migrant camp in its immediate surroundings also constituted domicide is crucial to understanding the current 'humanitarian' policing of migration extending across Europe. While this day center and 'tolerated jungle' was a new and seemingly positive development in the government response to the housing needs of illegalized border crossers in Calais, it was in fact tactic of segregation (Calais Migrant Solidarity 2015e; Tyerman 2016, 159-161) and part of a larger strategy to eliminate autonomous living spaces which might nurture anti-citizen politics (Calais Migrant Solidarity 2017, 64). As the number of arrivals increased during the 2015 'long summer of migration, so did the visible presence of migrants within Calais. Fearing the amount of people in Calais would continue to rise, Natacha Bouchart stated '[w]e 
think that the problem is going to get worse anyway so we need to do something to contain it. Perhaps the solution is to set up this centre...' in her address to the House of Commons asking for UK funding for the project (Home Affairs Committee 2015, $6)$.

The Jules Ferry center was then explicitly conceived of as a tool of containment and migration governance and not service provision. It was a spatial technology of 'noncitizen' segregation as, faced with an unprecedented number of people and having fears of those numbers continuing to grow, the French government chose to provide specific (albeit extremely minimal) services to migrants in Calais in the hopes of concentrating them outside the city center. Accompanied by the overwhelming force of the police and their more naked acts of domicide, this new humanitarianism functioned to consolidate migrant occupations into one area, far from the city, and with access to the rest of city only provided by two roads which could easily be closed by police. In addition to serving as a means of mobility control through distancing migrants from points of crossing at the Eurotunnel - although there continued to be frequent attacks on the motorway leading to the port which passed right next to the jungle (Calais Migrant Solidarity 2018) - both the humanitarian face of the Jules Ferry center and the violent domicide of other occupations throughout the city 'worked to contain the migrant population outside the ordinary places and public spaces of Calaisien citizenship' (Tyerman 2016, 161). This carrot-and-stick domicide, having since been repeated with the CAOs, produced this jungle as a space of citizenship's enclosure and migration governance. While it is not within the scope of this article to present a detailed account of the evolution of this jungle nor the repression, domicide, autonomous actions, resistances, or anti-citizen solidarities of its residents, it is important to recognize 'The Jungle's' emergence as part of a state strategy to visibly segregate migrants at a time when the state's previous strategy of evictions without solutions became untenable.

\section{Conclusion: Seeing through erasure}

It was an explicit decision in this article to focus upon citizenship as state exclusionary technology of migration governance and mobility control rather than elaborate on the spatial ruptures of migrants and their supporters. While it could be argued that focusing on state exclusionary practices reifies them, presents them as immutable, and denies the agency of those resisting them, this is not the intention behind the argument presented here. Rather than hardening the perception of France's border governance, carefully detailing domicide in Calais shows how the territorial segregation and destruction of communities of resistance is only the result of continuously reenacted state violence. It is only because of the constant disobedience and autonomy of illegalized border crossers that such a paranoid and hyperactive segregation exists today, with even the smallest spatial ruptures being stomped out quickly and overwhelmingly. From this current picture we can imagine the negative background of daily struggle by migrants to occupy and inhabit space in this city. Not elaborating upon the innumerable contentious forms of migrant inhabitance in Calais was done so as to allow the migrants themselves to decide how to tactically deploy the (in)visibility of their movements and spatial ruptures, and to contribute to redressing the amount of literature which expounds the politics of illegalized border crossers unsettling Europe's borders compared to that focusing on state repression. Each of the moments of domicide mentioned above was a reaction, and each of them are opportunities for researching and uncovering the resistant logics and spaces which have been erased. 
By paying careful attention to state domicide, and its attempts to hide and obscure struggle, we can look beneath the givenness of the city-space of Calais in order to see how it has been cultivated to produce or prevent interactions between groups of people (e.g. residents and migrants, citizens and others). These interactions are governed by a regime of citizenship which orders space just as it is ordered by space. However, space is not atemporal but rather is fundamentally constructed by and through time, and is also fundamental in the construction of narrative and history. Recognizing temporality allows us to see beyond the flat surface of Calais as something already given, and allows for us to see how it has been created through struggle. María Lugones writes that 'to understand the spatiality of our lives is to understand that oppressing/being oppressed $\Leftrightarrow$ resisting construct space simultaneously and that the temporality of each, at their infinite intersections, produces multiple histories/stories' (Lugones 2003, 12). By understanding space as temporal it must be recognized that the erasure of the spatiality of resistance, in this case the domicide of anti-citizen inhabitance in Calais, is also an attempt to erase those histories of resistance.

These attempts at spatial and historical erasure of citizenship's 'others', and their stories of anti-citizen resistance, is an always incomplete task requiring constant reenactment. Although today in Calais, due to the huge amount of resources the state has directed to constantly enacting domicidal interventions, it is difficult to imagine or reenact resistant spatial occupations (although they are nevertheless occurring). By paying close attention to how space and normative citizenship is constructed through the repression of dissident spatial ruptures, we can begin tracing the moves which have obscured resistances normative forms of citizenship and spatial inhabitance. By recognizing the interventions of domicide and the anti-coalitional citizenship logics which have produced the present, it is possible to begin scratching beneath the surface and discover the obscured and invisibilized resistant histories from which to take inspiration in the future.

\section{Acknowledgments}

My sincere thanks goes to the CAPPE Social Movements Network at the University of Brighton, friends and colleagues, and the two anonymous reviewers whose challenging and insightful feedback on earlier versions of this work were indispensable in helping to think through and revise this article.

\section{References}

Anderson, Bridget, Nandita Sharma, and Cynthia Wright. 2009. "Editorial: Why No Borders?" $26(2): 14$.

Anderson, Bridget, Nandita Sharma, and Cynthia Wright. 2012. "'We Are All Foreigners": No Borders as a Practical Political Project." In Citizenship, Migrant Activism and the Politics of Movement, edited by Peter Nyers and Kim Rygiel, 73-91. London: Routledge.

Ansems de Vries, Leonie, Lara Montesinos Coleman, Doerthe Rosenow, Martina Tazzioli, and Rolando Vázquez. 2017. "Fracturing Politics (or, How to Avoid the Tacit Reproduction of Modern/Colonial Ontologies in Critical Thought)." International Political Sociology 11 (1): $90-108$.

Ansems de Vries, Leonie, and Marta Welander. 2016. "Refugees, Displacement, and the European 'Politics of Exhaustion'." Sep. Accessed 2019-05-05. https://www. opendemocracy . net/en/mediterranean-journeys-in-hope/refugees-displacement-and-europ/. 
Ataç, Ilker. 2016. "'Refugee Protest Camp Vienna': Making Citizens through Locations of the Protest Movement." Citizenship Studies 20 (5): 629-646.

Ataç, Ilker, Kim Rygiel, and Maurice Stierl. 2016. "Introduction: The Contentious Politics of Refugee and Migrant Protest and Solidarity Movements: Remaking Citizenship from the Margins." Citizenship Studies 20 (5): 527-544.

Balibar, Etienne. 2009. "Europe as Borderland." Environment and Planning D: Society and Space 27 (2): 190-215.

Brandzel, Amy L. 2016. Against Citizenship: The Violence of the Normative. Champaign, IL: University of Illinois Press.

Buchanan, Sara, and Bethan Grillo. 2004. "What's the Story?: Reporting on Asylum in the British Media." Forced Migration Review 19. http://www.fmreview.org/ reproductive-health/buchanan-grillo.html.

Calais Migrant Solidarity. 2013a. "Decision of Victor Hugo Given... but Not to Us!" Accessed 2018-06-11. https://calaismigrantsolidarity.wordpress.com/2013/11/20/ decision-of-victor-hugo-given-but-not-to-us/.

Calais Migrant Solidarity. 2013b. "No Eviction!" Dec. Accessed 2018-06-11. https:// calaismigrantsolidarity . wordpress.com/2013/12/07/no-evacuation/.

Calais Migrant Solidarity. 2015a. "Eviction Is a Process." Mar. Accessed 2018-05-06. https: //calaismigrantsolidarity.wordpress.com/2015/03/29/eviction-is-a-process/.

Calais Migrant Solidarity. 2015b. "The Evictions Have Started / Les Expulsions Ont Commencé." Mar. Accessed 2018-06-09. https: //calaismigrantsolidarity.wordpress.com/ 2015/03/30/the-evictions-have-started/.

Calais Migrant Solidarity. 2015c. "Evictions in Calais and Paris." Jun. Accessed 2018-06-10. https://calaismigrantsolidarity.wordpress.com/2015/06/02/ evictions-in-calais-and-paris/.

Calais Migrant Solidarity. 2015d. "Evictions: Last 5 Homes of Refugees in Calais Ville Destroyed, Apartheid Alive and Well in Calais." Sep. Accessed 2017-12-17. https://calaismigrantsolidarity.wordpress.com/2015/09/21/ syrian-camp-destroyed-fascism-alive-and-well-in-calais/.

Calais Migrant Solidarity. 2015e. "Jules Ferry Centre: Another Step towards Segregation // Le Centre Jules Ferry: Un Autre Pas Vers La Segregation." Jan. Accessed 2018-05-06. https://calaismigrantsolidarity.wordpress.com/2015/01/29/ jules-ferry-centre-another-steps-towards-segregation-le-centre-jules-ferry-un-autre-pas-vers

Calais Migrant Solidarity. 2015f. "Why We Are Not Moving ; from Residents of Galloo." Apr. Accessed 2018-06-10. https://calaismigrantsolidarity.wordpress.com/2015/04/01/ why-we-are-not-moving-from-residents-of-galloo/.

Calais Migrant Solidarity. 2016. "Updates on Eviction in Calais." Oct. Accessed 2018-10-03. https://calaismigrantsolidarity.wordpress.com/2016/10/24/ updates-on-eviction-in-calais/.

Calais Migrant Solidarity. 2017. "Trapped on the Border: A Brief History of Solidarity Squatting Practices in Calais." In Migration, Squatting and Radical Autonomy, edited by Pierpaolo Mudu and Sutapa Chattopadhyay, 54-64. London and New York: Routledge.

Calais Migrant Solidarity. 2018. "Riots' in the Jungle: Collective Refusal and Resistance in Calais." In Riots and Militant Occupations: Smashing a System, Building a World - A Critical Introduction, edited by Andrew Robinson and Alissa Starodub. London: Rowman \& Littlefield.

Calais Research. 2017. "Intro to Calais." Accessed 2018-08-25. https://calaisresearch. noblogs.org/intro-to-calais/.

Calais Writers. 2017. Voices from the 'Jungle': Stories from the Calais Refugee Camp. London: Pluto Press.

Darling, Jonathan. 2017. "Acts, Ambiguities, and the Labour of Contesting Citizenship." Citizenship Studies 21 (6): 727-736.

Davies, Thom, and Arshad Isakjee. 2015. "Geography, Migration and Abandonment in the Calais Refugee Camp." Political Geography 49: 93-95. 
Davies, Thom, Arshad Isakjee, and Surindar Dhesi. 2017. "Violent Inaction: The Necropolitical Experience of Refugees in Europe." Antipode 49 (5): 1263-1284.

De Genova, Nicholas. 2007. "The Production of Culprits: From Deportability to Detainability in the Aftermath of "Homeland Security"." Citizenship Studies 11 (5): 421-448.

De Genova, Nicholas. 2017. "Citizenship Shadow; Obscene Inclusion, Abject Belonging, or, the Regularities of Migrant Irregularity." In Within and Beyond Citizenship: Borders, Membership and Belonging, edited by Roberto G. Gonzales and Nina Sigona, 17-35. Abingdon: Routledge.

Délinquants Solidaires. 2018. "Délit de solidarité: une association accusée d'avoir distribué des tentes à Calais." Mar. Accessed 2018-05-19. https://www.delinquantssolidaires.org/item/ delit-de-solidarite-une-association-accusee-davoir-distribue-des-tentes-a-calais.

Diaz, Charles, Ramdane Ouali, Olivier Paquette, Hervé Masurel, Medji Jamel, and Michel Duclap. 2017. Evaluation de l'action Des Forces de l'ordre à Calais et Dans Le Dunkerquois. Technical Report. Inspection générale de la police nationale, Inspection générale de l'administration, Inspection générale de la gendarmerie nationale. https://www.interieur.gouv.fr/content/download/105744/837794/file/ $20171023 \backslash \% 20-\backslash \% 20$ Rapport $\ \% 20 I G A-I G P N-I G G N(1)$. PDF.

Fortier, Anne-Marie. 2016. "Afterword: Acts of Affective Citizenship? Possibilities and Limitations." Citizenship Studies 20 (8): 1038-1044.

Hindess, Barry. 2004. "Citizenship for All." Citizenship Studies 8 (3): 305-315.

Home Affairs Committee. 2015. The Work of the Immigration Directorates: Calais Eighteenth Report of Session 2014-15. Technical Report. https://publications.parliament.uk/pa/ cm201415/cmselect/cmhaff/902/902.pdf.

Isin, Engin F. 2002. Being Political: Genealogies of Citizenship. Minneapolis, MN: University of Minnesota Press.

Isin, Engin F, and Greg M. Nielsen. 2008. Acts of Citizenship. London: Zed Books.

King, Natasha. 2016. No Borders: The Politics of Immigration Controls and Resistance. London: Zed Books.

La Voix du Nord. 2014a. "Calais : le squat Victor-Hugo sera libéré la semaine prochaine." Jun. Accessed 2018-06-11. http://www.lavoixdunord.fr/archive/recup \\%3A $\% 252$ Fregion $\backslash$ $\% 252 \mathrm{Fcal}$ ais-le-squat-victor-hugo-sera-libere-la-semaine-prochaine-ia33b0n2239894.

La Voix du Nord. 2014b. "Squat Victor-Hugo à Calais : l'association Solid'R a commencé à rencontrer les femmes migrantes." May. Accessed 2018-06-11. http://www.lavoixdunord.fr/archive/recup/region/ squat-victor-hugo-a-calais-l-association-solid-r-a-ia33b48581n2156212.

L'Auberge des Migrants, Utopia 56, Help Refugees, and Refugee Info Bus. 2018. Police Violence in Calais: Abusive and Illegal Practices by Law Enforcement Officers. Technical Report. Accessed 2018-01-12. https://helprefugees.org/wp-content/uploads/2018/08/ Police-Harrassment-of-Volunteers-in-Calais-1.pdf.

Le Figaro. 2015. "Renforcement de La Loi Contre Les Squatteurs." Le Figaro Accessed 2018-04-29. http://www.lefigaro.fr/flash-actu/2015/06/11/ 97001-20150611FILWWW00298-renforcement-de-la-loi-contre-les-squatteurs .php.

Lugones, María. 2003. Pilgrimages/Peregrinajes: Theorizing Coalition Against Multiple Oppressions. Lanham, MD: Rowman \& Littlefield.

Maestri, Gaja, and Sarah M. Hughes. 2017. "Contested Spaces of Citizenship: Camps, Borders, and Urban Encounters." Citizenship Studies 21 (6): 625-639.

Mezzadra, Sandro, and Brett Neilson. 2013. Border as Method, or, the Multiplication of Labor. Durham and London: Duke University Press.

Mould, Oli. 2017a. "The Calais Jungle: A Slum of London's Making." City 21 (3-4): 388-404.

Mould, Oli. 2017b. "The Not-so-Concrete Jungle: Material Precarity in the Calais Refugee Camp." cultural geographies 1-7.

Mudu, Pierpaolo, and Sutapa Chattopadhyay, eds. 2017. Migration, Squatting and Radical Autonomy. London and New York: Routledge. 
Nowicki, Mel. 2014. "Rethinking Domicide: Towards an Expanded Critical Geography of Home: Rethinking Domicide." Geography Compass 8 (11): 785-795.

Nowicki, Mel. 2017. "Domicide and the Coalition: Austerity, Citizenship and Moralities of Forced Eviction in Inner London." In Geographies of Forced Eviction: Dispossession, Violence, Resistance, edited by Katherine Brickell, Melissa Fernández Arrigoitia, and Alexander Vasudevan, 121-143. London: Palgrave Macmillan.

Nyers, Peter. 2015. "Migrant Citizenships and Autonomous Mobilities." Migration, Mobility, $\&$ Displacement 1 (1).

Nyers, Peter, and Kim Rygiel, eds. 2012. Citizenship, Migrant Activism and the Politics of Movement. Abingdon: Routledge.

Papadopoulos, Dimitris, and Vassilis Tsianos. 2013. "After Citizenship: Autonomy of Migration, Organisational Ontology and Mobile Commons." Citizenship Studies 17 (2): 178-196.

Porteous, J. Douglas, and Sandra E. Smith. 2001. Domicide: The Global Destruction of Home. Montreal and Kingston: McGill-Queens University Press.

Refugee Info Bus. 2018a. "6 Forced Evictions Have Taken Place This Week in Calais. More than One a Day for the Period When These 'Operations' Can Be Conducted. Tents and Belongings Taken, No Solutions Provided \#calais \#humanrightspic.Twitter.Com/7jfB1FKcnr." Jun. Accessed 2018-06-11. https://twitter.com/ RefugeeInfoBus/status/1002914036160266240.

Refugee Info Bus. 2018b. "Over the Weekend, French Police Came to 2 Living Places in Calais with Sharp Objects and Destroyed Tents, Whilst People Went to Access Breakfast Distributions. These Destructions Are Inhumane and Illegal \#Calais \#HumanRightsViolationspic.Twitter.Com/ONdmLDXV6T." May. Accessed 2018-06-11. https://twitter. com/RefugeeInfoBus/status/1001354123579621376.

Refugee Info Bus. 2018c. "Yesterday, Another Forced Eviction Took Place at a Living Point, in Calais. These Evictions Take Place between 3-5 Times a Week. Here, a 15 Year Old Minor Explains to Police That His Food Is inside the Tent That Is Being Illegally Taken Away \#HumanRights \#Calais \#Refugeespic.Twitter.Com/WEf4StcEbj." May. Accessed 2018-06-11. https://twitter.com/RefugeeInfoBus/status/999667564170108928.

Reuters. 2016. "Empty Makeshift Shelters Burn in Calais "Jungle"." Oct. Accessed 2018-10-03. https://reuters.screenocean.com/record/83755.

Rigby, Joe, and Raphael Schlembach. 2013. "Impossible Protest: Noborders in Calais." Citizenship Studies 17 (2): 157-172.

Rygiel, Kim. 2011. "Bordering Solidarities: Migrant Activism and the Politics of Movement and Camps at Calais." Citizenship Studies 15 (1): 1-19.

Solla, Andrés, and Carmen Menendez. 2015. "French Police Use Teargas on Refugees in Calais Video." The Guardian Accessed 2018-06-10. http://www.theguardian.com/world/video/ 2015/sep/22/french-police-use-teargas-on-refugees-in-calais-video.

Tazzioli, Martina. 2017a. "Beyond Citizen Politics." In Tunisia as a Revolutionized Space of Migration, edited by Glenda Garelli and Martina Tazzioli, Mobility \& Politics, 69-88. New York, NY: Palgrave Pivot.

Tazzioli, Martina. 2017b. "Calais after the Jungle: Migrant Dispersal and the Expulsion of Humanitarianism." Jul. Accessed 2018-0820. https://www.opendemocracy.net/beyondslavery/martina-tazzioli/ calais-after-jungle-migrant-dispersal-and-expulsion-of-humanitarianis.

Tyerman, Thomas. 2016. "Border Struggles : Segregation, Migrant Solidarity, and Ethical Politics in Everyday Life." PhD Thesis, University of Manchester. http://ethos.bl.uk/ OrderDetails.do?uin=uk. bl . ethos . 722300.

Vincent, Elise. 2014. "Calais va rouvrir un centre d'accueil pour migrants." Le Monde.fr Accessed 2018-06-10. https://www.lemonde.fr/societe/article/2014/09/ 03/calais-va-rouvrir-un-centre-d-accueil-pour-migrants_4480871_3224.html.

Willsher, Kim. 2018. "France Will Not Allow Another Refugee Camp in Calais, Says Macron; French President Warns People Trying to Reach UK from Northern France That They Are at 'Dead End'." The Guardian . 